\title{
Implikasi Kegiatan Remote Sensing terhadap Kedaulatan Negara
}

\author{
Sri Wartini
}

\begin{abstract}
A remote sensing provides mankind life with a really big usefulness. However, its application leads a tension for the international community because it deals with the sovereignty of a country. In addition, the remote sensing activities often ignore the country boundaries, that is a country can be remotely sensed without being known by the remotely sensed country. This brings about a serious and controversial debate among developed and developing countries. On the one hand, developing countries desire the developed ones to honor their sovereignty. On the other hand, developing countries want to have the freedom of using outer space.
\end{abstract}

\section{Pendahuluan}

Kemajuan ilmu pengetahuan dan teknologi ruang angkasa membuka kesempatân yang cukup besar bagi berbagai pihak untuk melakukan kegiatan di ruang angkasa. Sejak berhasilnya Uni Soviet meluncurkan Sputnik pada tanggal 4 Oktober $1957,{ }^{1}$ perkembangan teknologi ruang angkasa mengalami kemajuan yang cukup pesat. Hal ini dapat dilihat dari berbagai jenis pesawat ruang

angkasa yang berhasil diluncurkan di ruang angkasa dengan berbagai tujuan.

Penciptaan alat-alat komunikasi yang menggunakan teknologi ruang angkasa telah membawa manfaat yang sangat bagi kelancaran informasi dan pertukaran budaya antar bangsa, sehingga tidak ada lagi batasbatas negara yang dapat menghalangi penyebaran informasi. Kemajuan di bidang

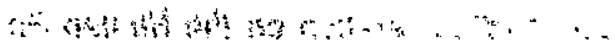

'Nicolas Mateesco Matte.1982: Aeraspäe Law Telecommunication Satellites. London: Blackstone Limited Press. HIm.1. 
komunikasi juga diikuti kemajuan yang sama dalam pemanfaatan satelit remote sensing (penginderaan jauh). ${ }^{2}$ Penginderaan jauh telah lama dikembangkan dalam kegiatan ruang angkasa. Dimulai ketika NASA meluncurkan LANSAT I pada tahun 1972. ${ }^{3}$ Pada awalnya penginderaan jauh hanya ditujukan untuk kegiatan riset, tetapi dalam perkembangannya penginderaan jauh juga menjadi kegiatan yang bersifat komersial.

Penginderaan jauh selain memberikan dampak positif bagi kehidupan manusia, seperti misalnya untuk kepentingan ramalan cuaca, pengelolaan sumber alam, pengamatan, pengawasan dan pengendalian bencana alam, dan pemetaan, penginderaan jauh juga dapat menimbulkan segenap konflik yang mengarah pada ketegangan internasional. Bahkan sewaktu-waktu dapat saja berubah menjadi tindak kekerasan, jika pemanfaatannya disalahgunakan, misalnya untuk tujuan matamata. Selain itu, dari segi pengaturannya juga banyak menimbulkan persoalan hukum, walaupun secara internasional permasalahan hukum tersebut telah berusaha dijembatani oleh United Nations Commisssion on the Peaceful Uses of Outer.Space (UN-COPUOS) ${ }^{4}$ yang telah berhasil merumuskan beberapa prinsip. Namun demikian, pertentangan antara negara yang diindera (the sensed state) dan negara pengindera (the sensing state) masih diwarnai pertentangan yang cukup tajam.

Sebagai salah satu bagian kegiatan ruang angkasa sudah barang tentu penggunaan satelit penginderaan jauh harus sesuai dengan ketentuan-ketentuan hukum internasional, terutama hukum Ruang Angkasa. Ternyata perangkat hukum tersebut belum memadai, padahal satelit penginderaan jauh termasuk salah satu penerapan teknologi ruang angkasa yang peka, jika ditinjau dari segi kepentingan nasional negara. Ini disebabkan sifat dari kegiatan penginderaan jauh tidak mengenal batas negara yang menyangkut data dan informasi yang bernilai strategis baik dari aspek pertahanan keamanan maupun kesejahteraan. Selain itu juga menyangkut masalah yang sangat fundamental yaitu mengenai kedaulatan niegara. ${ }^{5}$

2Diederiliks-Verschoor. "Current Issues in Remote Sensing." Michigan Yearbook of International Legal Studies. Hlm.305. Menyatakan: "Penginderaan jauh adalah suatu cara pengamatan dan analisis atau sumber daya alam di bumi dengan sensor yang dibawa oleh pesawat udara atau pesawat ruang angkasa. Penginderaan jauh juga menyangkut upaya pengumpulan data atas objek yang diindera baik di darat, laut, udara dan ruang angkasa serta upaya pemrosesan data secara kuantitatif maupun kualitatif."

${ }^{3}$ Marietta Benko. 1985. Willem de Gfaaff and Gijsbertha C.M.Reinjnen. Space Law in the United Nations. Netherlands: Martinus Nijhoff Publishers. Hilm.9.

4United Nations Commitee on the Peaceful Uses of Outer Space is bodyestablish in 1958 as an Ad Hoc Committee and composed of 53 States, A year later the Ad Hoc Committee was replaced by a permanent Committee on the Peaceful Uses of Outer Space The Committee has under consideration include the control of remote sensing of the earth particularly of natural resources by satelite. Dalam Nicolas Mateesco Matte. Op.Cit. HIm. 32.

sW.de Graaft and G.c.M. Reijnem. "Remote Sensing By Satelites." Dalam Marietta Benco, Willem de Fraaft and Gijsberat C.M, Reijnen. 1985. Space Law in The United Nations. Netheriands: Martinus Nijhoff Publishers. Him. 2. 
Di antara masalah hukum yang menonjol dalam kaitannya dengan kedaulatan negara adalah masalah kebebasan menggunakan ruang angkasa. Negara-negara maju, terutama Amerika berpendapat bahwa pengoperasian satelit penginderaan jauh adalah sesuai dengan prinsip penggunaan ruang angkasa secara bebas untuk maksud-maksud damai, sesuai Pasal 1 Spaces Treaty 1967,6 yaitu setiap negara bebas mempergunakan dan memanfaatkan ruang angkasa. Negaranegara berkembang sebaliknya berpendirian bahwa kebebasan ruang angkasa sebagaimana dimaksudkan oleh Pasal 1 Space treaty 1967 tidak boleh diterapkan begitu saja untuk penginderaan ruang angkasa, tetapi yang diindera adalah bumi, sehingga menyangkut kedaulatan negara lain. Karena itu harus ada ketentuan-ketentuan tambahan yang mengaturnya.

Semakin beragamnya konflik kepentingan yang ditimbulkan karena pemanfaatan penginderaan jauh (remote sensing) dalam masyarakat internasional, maka semakin banyak pula permasalahan yang harus segera ditangani. Dalam tulisan ini, penulis hanya membahas lebih lanjut tentang implikasi hukum kegiatan penginderaan jarak jauh di ruang angkasa terhadap kedaulatan negara, serta sampai sejauh mana perlindungan hukum yang diberikan oleh hukum ruang angkasa terhadap negara yang diindera.

\section{Remote Sensing}

Secara umum remote sensing (penginderaan jauh) terdiri dari dua bagian yaitu segmen angkasa space segment dan segmen bumi ground segment, segmen angkasa terdapat perangkat teknik dan operasional, seperti perangkat pengatur parameter orbit, perangkat sensor dan perangkat pengumpul data, serta perangkat komunikasi data ke daratan. Segmen bumi terdiri dari perangkat pengendali sensor dan satelit penerima data serta mendistribusikan data. Selain itu, pada segmen bumi juga terdapat perangkat pengolah data yang bertugas untuk mengolah data yang berasal dari penginderaan jauh yang diperoleh dari satelit menjadi data yang dimengerti. Perangkat pengolah data juga berfungși untuk menghasilkan produk yang memberikan nilai tambah atas data penginderaan jauh dari satelit.

Dengan demikian, dalam suatu sistem penginderaan jauh digunakan berbagai macam teknologi, baik yang menyangkut teknologi piranti keras (hardware) maupun piranti lunak (software) yang kebanyakan menggunakan teknologi tinggi (high technology). ${ }^{7}$ Jadi, secara singkat segmen bumi berfungsi menerima, mengkonferensi, menginterprestasi dan mendistribusikan data. Fungsi yang terakhir ialah yang menyebabkan pro dan kontra masyarakat international, khususnya negara berkembang dan negara maju.

${ }^{6}$ Treaty on Principles Concerning the Activities of States in the Exploration and Use of Outer Space, Including the Moon and Other Celestial Bodies.

${ }^{7}$ Mieke Komar Kantaatmadja. Laporan Akhir Naskah Akademis Peraturan Perundang-undangan Tentang Hak Milik Intelektual Dalam Kegiatan Penginderaan Jauh. BPHN. Tahun 1995/1996. HIm.2-5 
Beberapa usaha telah dilakukan oleh United Nations Committee on The Peaceful Uses of Outer space (UN-COPOUS) untuk memberikan definisi remote sensing supaya diperoleh definisi yang tepat. Berikut ini adalah definisi yang diberikan oleh General Assembly of the. Working Group on Remote sensing of the Earth by Satelite pada tanggal 15 Maret 1978 yang menyatakan:

Remote sensing of the earth from space is a methodology to assist in characterizing the quality and condition of natural resources, geographical features and phenomena and earth's environment by means of measurements from space platform. ${ }^{8}$

Di samping itu Lillesand dan Kiefer mendefinisikan Penginderaan jauh sebagai berikut:

Remote sensing is the science and art of obtaining information about and object area or phenomena through the analysis of data acquired by device that is not in contact with the object area or phenomena under investigation. 9 .

Mengingat kedua definisi tersebut bukan merupakan definisi yang dirumuskan dalam suatu ketentuan hukum, sehingga masingmasing pihak dapat menafsirkannya sesuai dengan kehendak dan kepentingannya. Untuk menghindarkan hal itu berikut ini adalah definisi yang memiliki kekuatan hukum dalam perumusannya. Definisi ini dituangkan dalam bentuk Resolusi oleh Perserikatan Bangsa Bangsa (PBB), walaupun suatu Resolusi tidak dapat dikatakan sebagai suatu ketentuan hukum yang mengikat, tetapi suatu Resolusi dapat dikatakan sebagai salah satu sumber Hukum Internasional. Rumusan penginderaan jauh melalui satelit yang dikemukakan oleh PBB melalui Resolusi 41/65 tahun 1988 menyatakan:

Remote sensing by satellite is the sensing of the earth's surface from space by making use of the properties of electromag-

- netic waves enmitted, refelected by the sensed objects for the purpose of improving natural resources management, land use and the protection of environment. ${ }^{10}$

Dari ketiga definisi itu masing-masing memberikan pengertian yang berbeda, namun ketiganya ada persamaan bahwa remote sensing yang dipergunakan untuk penginderaan ini tidak pemah kontak fisik dengan objek yang diinderanya. Ketiganya penginderaan jauh selain mencakup pengoperasian remote sensing dari luar angkasa juga termasúk pengumpulan data primer, stasiun penyimpanan, aktivitas pemrosesan data, penginterprestasian data dan penyebaran data yang telah diproses.

${ }^{8}$ N.M.Matte dan H.De Saussre. 1976. Legal Implication of Remote Sensing From Outer Space, A.W.Sijhoff: Leyden. HIm.76.

${ }^{9}$ Dideriks Verschoor. Op.Cit. Hilm. 307.

${ }^{10}$ Principle 1 (a) UN Resolution 41/65 on Principle Relating to Remote Sensing of Earth from Uoter Space, Adopted on December 3, 1986. 


\section{Status Hukum Penginderaan Jauh Melalui Satelit}

Di manakah sebetulnya penginderaan jauh melalui satelit diatur oleh hukum ruang angkasa? Untuk dapat menjawab pertanyaan ini, maka harus diteliti asal usul hukum ruang angkasa dan meninjau kembali peristiwaperistiwa di Perserikatan Bangsa Bangsa sejak akhir tahun 1950-an sampai sekarang. Perserikatan Bangsa Bangsa menyadari bahwa implikasi yang serius penggunaan satelit remote sensing adalah dalam bidang militer."

Pengoperasian penginderaan jauh telah dijadikan bahan perundingan di UNCOPŨOS yang berusaha keras untuk menciptakan suatu perangkat perjanjian internasional. Beberapa negara terutama negara-negara berkembang berpendirian kuat agar perjanjian tentang penginderaan jauh yang menggunakan satelit di ruang angkasa hendaknya harus dapat. menjamin hak negara-negara yang ada di bawahnya. Hak-hak negara ini antara lain dalam mengakses data hasil penginderaan jauh, juga hak untuk dihormati kedaulatannya, misalnya dengan persetujuan lebih dulu (prior consent) dari negara yang diindera.

Masalah pokok mengenai penginderaan jauh ialah apakah kegiatan tersebut termasuk pemanfaatan ruang angkasa sebagaimana yang dimaksud dalam Space Treaty tahun 1967 dan oleh karenanya, tunduk pada Treaty ini. Kegiatan penginderaan jauh tersebut berorientasi ke bumi (earth oriented), sehingga kegiatan tersebut dapat dibagi dua, yaitu; mengenai satelit penginderaan jauh itu sendiri yang mengorbit di ruang angkasa berlaku sepenuhnya prinsip-prinsip Space Treaty 1967. karena memang kedudukan satelit tersebut berada di wilayah yang tidak satu negarapun dapat melaksanakan kedaulatannya. ${ }^{12}$ Kegiatan penginderaan itu sendiri merupakan kegiatan yang tidak seluruhnya tunduk pada prinsip-prinsip tersebut.

Perjanjian Internasional ruang angkasa (Outer Space Treaty) 1967 berisi tentang prinsip-prinsip umum hukum ruang angkasa yang diterapkan pada semua aktivitas ruang angkasa termasuk penginderaan jauh. Prinsipprinsip yang dimuat dalam Outer Space Treaty dapat diringkas sebagai berikut:13

1. Prinsip tidak dapat dimiliki (non-appropriation principle)

2. Prinsip kebebasan eksplorasi dan pemanfaatan (freedom of exploration and use).

3. Prinsip bahwa Hukum Internasional umum berlaku, termasuk Piagam PBB

"Pada tanggal 12 Desember 1959, Majelis Umum PBB membentuk dua Sub Komite yaitu Legal Sub Committee dan Scientific and Technical Sub Committee untuk membantu UN-COPUOS dalam menjalankan tugasnya. Kemudian pada tahun 1971 dibentuklah sebuah kelompok kerja (working group) untuk membantu Sub Komite Hukum dalam memecahkan masalah yang berhubunugan dengan penginderaan jauh.

${ }^{12}$ Hanneke Louise van Traa-Engelman. 1989. Commercial Utilization of Outer Space Legal Aspect. Netherlands. HIm.172.

${ }^{13}$ Ida Bagus Rahmadi Supancana. "The Contribution of the Developing Countries to the Legal Formulation of Future Space Law." Dalam Tanja L,Zwaan, Editor in Chief. 1989. Space Law: Views of the Future, London: Kluwer Law and Taxation Publishers. HIm. 117. 
(applicability of general international law including the United Nations Charter)

4. Prinsip pembatasan kegiatan militer (restriction of military activities) .

5. Prinsip common interest dan common heritage.

6. Status ruang 'angkasa sebagai res extra commercium atau res omnium communis).

7. Prinsip kerja sama internasional '(international cooperation)

8. Prinsip tanggung jawab (responsibility and liability principle)

Sepintas lalu sepertinya prinsip-prinsip ini harus berlaku pula untuk penginderaan jauh. Namun, kalau dilihat prinsip-prinsip tersebut lebih lanjut; maka akan timbul suatu permasalahan.

Prinsip pertama bahwa ruang angkasa tidak dapat dimiliki, jelas hanya relevan untuk ruang angkasa termasuk bulan dan bendabenda langit lainnya. Satelit itu sendiri dimiliki oleh suatu negara tertentu atau suatu badan hukum yang memiliki kebangsaan tertentu. Kebangsaan satelit dibuktikan dengan adanya pendaftaran sesuai yang diatur dalam Convention Concering the Registration of Objects Launched into Space for the Exploration or Use of Outer Space, 1975 yang mewajibkan negara yang meluncurkan satelit untuk mendaftarkannya pada Sekjen PBB.

Prinsip kedua, yaitu kebebasan eksplorasi dan pemanfaatan, dapat ditafsirkan sebagai kebebasan untuk melakukan kegiatankegiatan di ruang angkasa. Setidak-tidaknya prinsip ini berlaku bagi kegiatan yang space oriented, akan tetapi apakah berlaku juga bagi kegiatan yang earth oriented? Dalam hal ini memungkinkan adanya pertentangan antara prinsip, misainya prinsip kedaulatan negara yang diindera dengan prinsip kebebasan, kecuali kalau yang diindera wilayahnya sendiri.

Prinsip berlakunya hukum internasional umum mengandung pula kemungkinan konflik antara prinsip dalam Space Treaty dan prinsip Hukum Internasional umum, sebagai mana disebutkan di atas, misalnya prinsip kedaulatan. Prinsip kedaulatan ini bertentangan pula dengan free flow of information (Pasal 19 United Nations Universal Declaration of Human Rights): Di samping itu prinsip free flow of information bertentangan pula dengan kedaulatan suatu negara atas sumber alamnya dan mungkin juga atas informasi mengenai sumber alam tersebut dalam arti seluasIuasnya. ${ }^{14}$

Walaupun Space Treaty tahun 1967 tidak mengatur secara langsung mengenai penginderaan jauh, tetapi pasal satunya memuat prinsip-prinsip dasar kegiatan ruang angkasa, untuk keuntungan dan kepentingan semua negara. Penginderaan jauh melalui satelit dalam pengoperasiannya selain memanfaatkan ruang angkasa juga memanfaatkan stasiun , bumi. Hasil penginderaan dikumpulkan 'dan diproses di bumi, kemudian akan didistribusikan dan dipergunakan di bumi. ${ }^{15}$

Penginderaan jarak jauh yang dilakukan dari ruang angkasa sering menimbulkan konflik antara negara yang mengindera dengan

${ }^{14}$ Nicolas Mateesco Matte (Ed). 1984. Space Activities and Emerging International Law. Him.401

${ }^{15}$ Hanneke Louise van Traa-Engelman. Op.Cit. HIm.173. 
negara yang diindera, jika tidak ada persetujuan lebih dahulu (prior consent). Konflik ini terjadi karena berkaitan dengan masalah "kedaulatan" negara. Bagi negaranegara yang diindera tanpa adanya pemberitahuan dan persetujuan lebih dahulu merasa bahwa kedaulatannya dilanggar. Bagi negara yang mengindera merasa bahwa ia tidak melanggar kedaulatan negara lain, karena penginderaan dilakukan di ruang angkasa yang tidak menjadi wilayah kedaulatan negara manapun. Konflik inilah yang sedang diusahakan jalan pemecahannya. Space Treaty tahun 1967 yang berisi prinsip-prinsip dasar pemanfaatan ruang angkasa belum dapat dijadikan sebagai landasan untuk memecahkan masalah ini.

\section{Kedaulatan Negara}

Sebagaimana ditentukan di dalam Pasal 1 Konvensi Montevideo 1933, bahwa salah satu unsur pokok untuk dapat disebut sebagai negara adalah penguasaan suatu wilayah territorial. Wilayah negara sebagai suatu ruang meliputi daratan, perairan dan ruang udara. Wilayah daratan dan wilayah udara dimiliki oleh setiap negara, sedangkan wilayah laut hanya dimiliki oleh negara pantai atau negara yang di hadapan pantainya terdapat laut.

Oleh karena itu, muncullah konsep "kedaulatan territorial" yang menandakan bahwa di dalamnya wilayah kekuasaan ini yurisdiksi dilaksanakan oleh negara terhadap orang-orang dan harta benda secara eksklusif.
Hakim Huber dalam kasus Island of Palma menyatakan bahwa dalam kaitannya dengan wilayah, kedaulatan memiliki dua ciri yang sangat penting yang dimiliki oleh suatu negara. Ciri pertama, yaitu; kedaulatan merupakan suatu prasarat hukum untuk adanya suatu negara. Ciri kedua, kedaulatan menunjukkan negara tersebut merdeka dan sekaligus juga merupakan fungsi dari suatu negara. Pernyataan Huber adalah sebagai berikut: ${ }^{16}$

Soveregnty in relation to aportion of the surface of the globe is the legal condition necessary for the inclusion of such portion in the territory of any particular state.

Selain itu beliau juga menyatakan: ${ }^{17}$

Sovereignty in the relation between states signifies independence. Independence in regard to a portion of the globe is the righ to exercise therein, to the exclusion of any other state, the function of a state.

Dari pernyataan beliau tersebut dapat ditarik suatu pengertian bahwa suatu negara tidak dapat melaksanakan yurisdiksi esklusifnya ke luar dari wilayahnya yang dapat mengganggu kedaulatan wilayah negara lain. Suatu negara hanya dapat melaksanakannya secara eksklusif dan penuh hanya di dalam wilayahnya saja. Kedaulatan negara ini mempunyai aspek positif dan negatifnya. Aspek positif yang dimaksud ialah berkaitan dengan sifat hak eksklusif kompetensi suatu negara terhadap wilayahnya. Aspek negatif kedaulatan territorial ini adalah kewajiban

${ }^{16}$ M.N. Shaw. 1986. International Law. London: Butterworhts. HIm.240

${ }^{17}$ J.G. Starke. 1984. Introduction to Intenational Law. Edisi ke-9. London: Butterworhts. HIm. 152 
untuk tidak mengganggu hak negara-negara lain. ${ }^{18}$ Kesimpulan ini tampak pada pernyataan Hakim Huber dalam kasus the Islan of Palma, di mana beliau menyatakan sebagai berikut:

Territorial sovereignty involces the exclusive right to display the activities of a state. The right has as its corollary a duty; the duty to pretect within the territory the rights odd other states, together with the rights which each state may claim for its nationals in foreign territory.

Kedaulatan negara adalah merupakan kekuasaan tertinggi dari suatu negara Ini berarti di atas kedaulatan itu tidak ada lagi kekuasaan yang lebih tinggi lagi. Kedaulatan yang dimiliki oleh suatu negara menunjukkan bahwa suatu negara adalah merdeka atau tidak tunduk pada kekuasaan negara lain. Hal ini tidak dapat diartikan bahwa kedaulatan itu tidak ada yang membatasi, atau sebagai tidak terbatas sama sekali. Pembatasannya sendiri adalah hukum nasional maupun hukum internasinoal.

Kedaulatan itu pada dasamya mengandung dua aspek. Pertama, aspek internal yaitu berupa kekuasaan tertinggi untuk mengatur segala sesuatu yang ada atau terjadi di dalam batas-batas wilayảhnya. Kedua, aspek eksternal yaitu kekuasaan tertinggi untuk mengadakan hubungan dengan anggota masyarakat internasional maupun mengatur segala sesuatu yang berada atau terjadi di luar wilayah negara itu, tetapi sepanjang masih ada kaitannya dengan negara itu. Kedaulatan territorial suatu negara mencakup tiga dimensi, yang terdiri dari tanah (daratan) yang: mencakup segala yang ada di bawah dan di atas tanah, misalnya kekayaan alam dan. segala sesuatu yang tumbuh di atas tanah, laut dan udara.

\section{Implikasi Kegiatan Remote Sensing terhadap Kedaulatan Negara}

Penginderaan jauh sebagai salah satu dari sekian banyak penerapan ilmu pengetahuan dan teknologi ruang angkasa, dalam penerapannya menimbulkan pro dan kontra dalam masyarakat internasional, karena ada kaitannya dengan masalah kedaulatan negara.

- Mengenai prinsip kedaulatan, negaranegara maju berpendapat kegiatan penginderaan jauh tidak melanggar prinsip kedaulatan dalam hukum internasional. Alasan mereka ialah meskipun objek yang diindera di wilayah nasional negara lain, tetapi tempat penginderaan adaläh di luar wilayah kedaulatan negara manapun. Negara berkembang berpendirian prinsip kedaulatan mencakup pula hak eksklusif setiap negara atas kekayaan alamnya. Ini sesuai dengan Resolusi Majelis Umum Perserikatan BangsaBangsa No.1803 (VII) tanggal 14 Desember 1962 tentang Permanent Sovereignty of States over Natural Resources. Dalam Resolusi tersebut, dinyatakan bahwa setiap negara mempunyai kedaulatan penuh dan bersifat tetap atas kekayaan alamnya. Kedaulatan demikian, ${ }^{N}$ mencakup pula informasi

${ }^{18}$ Hakim Huber dalam Island of Palma Case. 2 RIAA. HIm. 829, 838 (1928) sebagaimana dikutib oleh M.N, Shaw. Loc.Cit. 
mengenai sumber alam. Oleh karena itu, menurut negara sedang berkembang harus ada ijin terlebih dahulu dari negara yang berdaulat atas sumber alam, bila suatu negara akan mengindera dan menyebarkan informasi mengenai sumber alam negara tersebut, karena hal itu menyangkut kedaulatan yang harus dihormati dalam hukum internasional. ${ }^{19}$

\section{Masalah Kedaulatan Negara yang Menimbulkan Kontraversi}

Sebagaimana aktivitas-aktivitas ruang angkasa yang lain, kegiatan remote sensing mengabaikan batas-batas negara. Hal ini menimbulkan suatu konsekuensi yang sangat penting dan bahkan menimbulkan suatu pertentangan, karena suatu negara dapat diindera tanpa sepengetahuan yang bersangkutan. Masalah inilah yang kemudian menjadi suatu perdebatan yang serius antara negara berkembang dan negara maju. Di satus pihak negara berkembang menghendaki kedaulatan negaranya dihormati dan dilindungi, sedangkan negara maju menghendaki adanya suatu kebebasan dalam memanfaatkan ruang angkasa.

Mengapa negara berkembang. berkeberatan terhadap prinsip kebebasan dalam pemanfaatan ruang angkasa termasuk pengoperasian remote sensing? Keberatan ini berhubungan erat dengan masalah kedaulatan negara (state sovereignty). Kedaulatan negara sebagaimana diketahui, merupakan kekuasaan tertinggi dari. suatu negara. Kedaulatan yang dimiliki oleh suatu negara menunjukkan bahwa suatu negara adalah merdeka atau tidak berada pada kekuasaan negara lain, menurut Huber:

Sovereignty is synonymous with independence, Independence in regard to a portion of the globe is the reight to exerise there in, the exclusion of any other stae, the function of state, Territorial sovereignty .. involve the exclusive right to display the activities of a state.

Oleh karena itu, menimbulkan suatu kewajiban bagi negara untuk tidak melakukan intervensi terhadap kedaulatan territorial negara lain. Berdasarkan konsep kedaulatan tersebut negara berkembang berpendapat bahwa dalam pengoperasian remote sensing oleh negara-negara pengindera telah terjadi pelanggaran kedaulatan. Karena dalam pengoperasian remote sensing ini negara yang dirirdera biasanya tidak dimintai persetujuan lebih dahulu (prior consent).

Masalah kedaulatan dan prior consent inilah yang menjadi pertentangan antara negara pengindera dan yang diindera. Negaranegara yang diindera berpendapat bahwa sebelum negara-negara melakukan penginderaan jarak jauh, maka lebih dahulu harus mendapatkan ijin dari negara yang wilayahnya menjadi sasaran penginderaan, kemudian hasil penginderaan tersebut harus diberitahukan kepada negara yang menjadi objek penginderaan untuk mencegah terjadinya penyalahgunaan hasil atau data dari penginderaan tersebut. Hal ini dimaksudkan agar negara pengindera tidak menyebarluaskan tanpa persetujuan negara yang diselidiki atau diindera.

${ }^{19}$ Yasidi Hambali. 1984. Hukum dan Politik Kedirgantaraan. PT.Pradnya Paramita: Jakarta. HIm. 99. 
Negara-negara yang diindera pada umumnya adalah negara yang sedang berkembang yang tidak memiliki kemampuan teknologi tinggi ruang angkasa. Oleh karena itu, kondisi ketertinggalan teknologi tersebut, maka negara berkemibang menuntut adanya prinsip prior consent mengenai aplikasi teknologi ruang angkasa jenis ini. Hal ini menurut negara berkembang didasarkan pada konsepsi kedaulatan eksklusif terhadap segala sesuatu yang berada dan atau mengenai wilayah negara berkembang yang menjadi sasaran penginderaan itu. Tuntutan yang diajukan oleh negara-negara berkembang tersebut mendapat tantangan dari negara-negara maju. Amerika Serikat sebagai salah satu space power mengatakan bahwa dengan adanya prior consent akan menghambat perkembangan teknologi yang diharapkan bagi peningkatan taraf hidup manusia. Hal ini dapat diduga sebelumnya mengingat Amerika selalu menjaga supremasi ekonomi dan militer di dunia, ditambah pula bahwa remote sensing bukan hanya dapat digunakan untuk menyelidiki sumber-sumber alam saja, tetapi juga untuk mempelajari masalah lingkungan serta untuk keperluan pertanian.

Pertentangan pendapat dan kepentingan di antara negara-negara barat dan berkembang sendiri sulit untuk memperoleh jalan keluar. Negara Barat tetap berpegang teguh kepada apa yang mereka sebut kebebasan informasi.(freedom of information) dan tidak menghendaki dikaitkan dengan kedaulatan negara, sementara negara berkembang menekankan perlunya aspek kedaulatan, sehingga informasi atas sumbersumber alam tidak begitu saja dapat disebarluaskan secara bebas/tanpa ijin negara yang diindera.

\section{Masalah Prior Consent}

Prior consent berhadapan dengan freedom to sense. Apakah suatu negara harus mengajukan ijin kepada negara yang diindera? Mengingat regim hukum yang berlaku di ruang angkasa, maka ada yang berpendapat bahwa tidak perlu minta ijin terlebih dahulu dari negara yang diindera. Kebanyakan negara berkembang berpersepsi bahwa penginderaan jarak jauh tidak dilakukan tanpa adanya persetujuan lebih dulu dari negara yang diindera. Selain itu negara berkembang juga menuntut adanya persyaratan konsultasi terlebih dahulu kepada negara yang diindera untuk memperoleh keuntungan bersama. Namun oleh negaranegara Barat persepsi ini dinyatakan bertentangan dengan prinsip freedom of exploration and use of outher space sebagaimana diatur dalam Outer Space Treaty tahun 1967, sehingga mereka menolak permintaan negara yang dindera.

Masalah kedaulatan negara. yang diperdebatkan oleh negara berkembang dan negara maju, sèbetulnya merupakan perjuangan negara berkembang untuk mencapai kesepakatan dengan negara pengindera supaya mereka memberikan data dan informasi yang mereka peroleh dari kegiatan remote sensing. Dengan adanya pemberian data dan informasi dari negara pengindera akan sangat bermanfaat bagi negara yang diindera, baik untuk keperluan komunikasi, managemen; pengelolaan sumber alam maupun untuk perlindunugan lingkungan, sedangkan yang menjadi kekhawatiran negara yang diindera kalau tidak ada persetujuan lebih dulu antara lain ialah kalau data dan informasi tersebut disebarkan 
kepada pihak ketiga atau unutk negara pengindera dengan maksud untuk merugikan negara yang diindera.

\section{Upaya UN-COPUOS dalam Mengatasi Konflik Antara Negara Pengindera dengan Negara yang Diindera}

Dalam rangka memperoleh titik temu antara kepentingan negara pengindera dan yang diindera, peserta UN-COPUOS khususnya pada sidang-sidang Sub Komite Hukum akhirnya berhasil merumuskan prinsip-prinsip sebagai jalan tengah dari pertentangan di antara mereka.

Dari prinsip-prinsip yang dikemukakan oleh UN-COPUOS dapat ditarik suatu pengertian bahwa dalam rangka untuk mengkompromikan kepentingan negara sedang berkembang dan maju, Perserikatan Bangsa Bangsa dan agen-agen khususnya termasuk Badan Energi Atom Internasional mempromosikan dan mewajibkan kepada negara-negara melakukan pengoperasian remote sensing sebagai berikut:20

1. Kerjasama internasional termasuk pemberian bantuan teknik

2. Negara melakukan kegiatan remote sensing wajib melaporkan kepada Sekretaris Jenderal Perserikatan Bangsa Bangsa.

3. Data yang diperoleh dari remote sensing ataupun informasi, tidak boleh dipergunakan oleh negara-negara dengan maksud untuk merugikan kepentingan negara lain.

4. Negara-negara yang berpartisipasi dalam kegiatan remote sensing terhadap sumber-sumber alam atau lingkungan baik secara langsung atau tak langsung melalui organisasi internasional yang relevan untuk menyediakan data dari Perserikatan Bangsa Bangsa dan negaranegara yang berkepentingan, khususnya negara-negara berkembang, berdasarkan permintaan mereka mengenai informasi teknik yang relevan termasuk system operasional yang memungkinkan untuk diumumkan.

5. Negara-negara harus bertanggung jawab secara internasional atas kerugian remote sensing, baik kegiatan itu dilakukan oleh negara atau pihak swasta.

6. Negara-negara yang diindera harus diberi hak untuk mengakses data yang diperoleh dari kegiatan remote sensing.

7. Dalam pengoperasian remote sensing negara yang mengindera harus menghormati prinsip kedaulatan negara yang penuh dan tetap yang dimiliki oleh negara-negara.

Nampak prinsip-prinsip yang telah dihasilkan dalam sidang UN-COPUOS tersebut telah berusaha untuk mengimbangkan kepentingan negara maju dan negara berkembang, namun sayangnya negara maju tidak menyetujui prinsip yang terakhir tersebut, karena negara berkembang/yang diindera telah mengkaitkan soal informasi dengan kedaulatan suatu negara.

\section{Simpulan}

Kegiatan remote sensing. di satu pihak sangat menguntungkan bagi kehidupan umat

${ }^{20}$ Juajir Sumardi. Hukum Ruang Angkasa Suatu Pengantar. Jakarta: Pradnya Paramita. Hlm. 114-115. 
manusia, tetapi di lain pihak dapat merugikan kepentingan suatu negara. Masalah kedaulatan negara dan kebebasan informasi merupakan suatu masalah yang belum terpecahkan, karena negara-negara maju tetap berpegang pada prinsip freedom of exploration sebagaimana yang termuat dalam Space Treaty tahun 1967.

Prinsip-prinsip remote sensing masih tertuang dalam bentuk Resolusi Perserikatan Bangsa-Bangsa. Resolusi ini secara hukum belum merupakan suatu ketentuan yang mengikat sebagaimana perjanjian intemasional. Sehingga masih sangat memungkinkan untuk tidak ditaati- resolusi tersebut. Sebagai konsekuensi lebih lanjut perlindungan kedaulatan negara yang didambakan oleh negara-negara yang menjadi obyek penginderaan masih merupakan suatu perjuangan yang panjang.

\section{Daftar Pustaka}

Benko, Marietta. 1985. Willem de Gfaaff and Gijsbertha C.M.Reinjnen. Space Law in the United Nations. Netherlands: Martinus Nijhoff Publishers.

Engelman, Hanneke Louise van Traa: 1989. Commercial Utilization of Outer Space Legal 'Aspect. Netherlands.

Graaft, W.de and G.c.M. Reijnem. "Remote Sensing By Satelites." Dalam Marietta Benco, Willem de Fraaft and Gijsberat C.M, Reijnen. 1985. Space Law in The United Nations. Netherlands: Martinus Nijhoff Publishers.

Hambali, Yasidi.: 1984. Hukum dan Politik Kedirgantaraan. PT.Pradnya Paramita: Jakarta.
Huber, Hakim dalam Island of Palma Case. 2RIAA.

Kantaatmadja, Mieke Komar. Laporan Akhir Naskah Akademis Peraturan Perundang-undangan Tentang Hak Milik Intelektual Dalam Kegiatan Penginderaan Jauh. BPHN. Tahun 1995/1996.

Matte, N.M. dan H.De Saussre. 1976. Legal Implication of Remote Sensing From Outer Space, A.W.Sijhoff: Leyden.

Matte, Nicolas Mateesco (Ed). 1984. Space Activities and Emerging Interna'tional Law.

Matte, Nicolas Mateesco. 1982. Aeraspace Law Telecommunication Satellites. London: Blackstone Limited Press.

Shaw, M.N.. 1986. International Law. London : Butterworhts.

Starke, J.G. 1984. Introduction to Intenational Law: Edisi ke-9. London : Butterworhts.

Sumardi, Juajir. Hukum Ruang Arigkasa Suatu Pengantar. Jakarta: Pradnya Paramita.

Supancana, Ida Bagus Rahmadi. "The Contribution of the Developing Countries to the Legal Formulation of Future Space Law." Dalam Tanja L.Zwaan, Editor in Chief. 1989. Space Law: Views of the Future; London: Kluwer Law and Taxation Publishers.

Verschoor, Diederiliks. "Current Issues in Remote Sensing." Michigan Yearbook of International Legal Studies. 